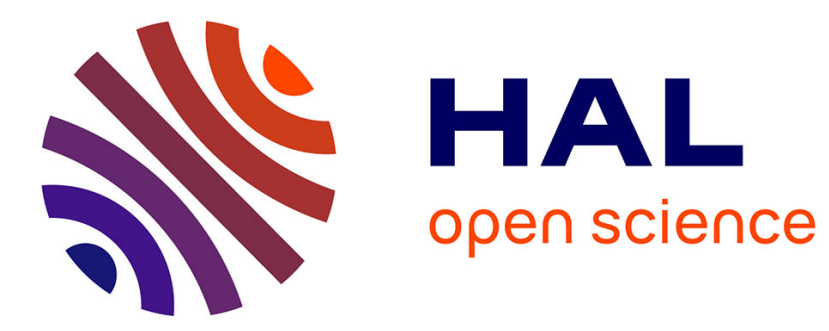

\title{
Characteristics and outcomes of patients with ophthalmologic involvement in giant-cell arteritis: a case-control study
}

Anaël Dumont

\section{- To cite this version:}

Anaël Dumont. Characteristics and outcomes of patients with ophthalmologic involvement in giantcell arteritis: a case-control study. Human health and pathology. 2019. dumas-02474167

\section{HAL Id: dumas-02474167 https://dumas.ccsd.cnrs.fr/dumas-02474167}

Submitted on 11 Feb 2020

HAL is a multi-disciplinary open access archive for the deposit and dissemination of scientific research documents, whether they are published or not. The documents may come from teaching and research institutions in France or abroad, or from public or private research centers.
L'archive ouverte pluridisciplinaire HAL, est destinée au dépôt et à la diffusion de documents scientifiques de niveau recherche, publiés ou non, émanant des établissements d'enseignement et de recherche français ou étrangers, des laboratoires publics ou privés. 
UNIVERSITÉ de CAEN NORMANDIE

FACULTÉ de MÉDECINE

Année 2018/2019

\section{THÈSE POUR L'OBTENTION}

\section{DU GRADE DE DOCTEUR EN MÉDECINE}

Présentée et soutenue publiquement le : 24 septembre 2019

par

M. DUMONT Anaël

Né le 18 août 1989 à REIMS (51)

\section{TITRE DE IA THESE:}

\section{Caractéristiques et évolution des manifestations ophtalmologiques dans 1'artérite à cellules géantes : une étude cas-témoin.}

Président : Monsieur le Professeur AOUBA Achille

Membres : Monsieur le Professeur QUYNTIN Jean-Claude

Monsieur le Dr De BOYSSON Hubert

Monsieur le Docteur MARTIN-SILVA Nicolas

Monsieur le Docteur DESHAYES Samuel

Directeur de thèse : $\mathrm{Dr}$ De BOYSSON Hubert 


\title{
Année Universitaire 2018/2019
}

\author{
Doyen \\ Professeur Emmanuel TOUZÉ \\ Assesseurs \\ Professeur Paul MILLIEZ (pédagogie) \\ Professeur Guy LAUNOY (recherche) \\ Professeur Sonia DOLLFUS \& Professeur Evelyne EMERY ( $3^{\text {ème }}$ cycle) \\ Directrice administrative \\ Madame Sarah CHEMTOB
}

\section{PROFESSEURS DES UNIVERSITÉS - PRATICIENS HOSPITALIERS}

M. AGOSTINI Denis

M. AIDE Nicolas

M. ALLOUCHE Stéphane

M. ALVES Arnaud

M. AOUBA Achille

M. BABIN Emmanuel

M. BÉNATEAU Hervé

M. BENOIST Guillaume

M. BERGER Ludovic

M. BERGOT Emmanuel

$M$. BIBEAU Frédéric

Mme BRAZO Perrine

M. BROUARD Jacques

M. BUSTANY Pierre

Mme CHAPON Françoise

Mme CLIN-GODARD Bénédicte

M. COQUEREL Antoine

M. DAO Manh Thông

M. DAMAJ Ghandi Laurent

M. DEFER Gilles

M. DELAMILLIEURE Pascal

M. DENISE Pierre

M. DERLON Jean-Michel Éméritat jusqu'au 31/08/2020

Mme DOLLFUS Sonia

M. DREYFUS Michel

M. DU CHEYRON Damien

Mme ÉMERY Evelyne

M. ESMAIL-BEYGUI Farzin
Biophysique et médecine nucléaire

Biophysique et médecine nucléaire

Biochimie et biologie moléculaire

Chirurgie digestive

Médecine interne

Oto-Rhino-Laryngologie

Chirurgie maxillo-faciale et stomatologie

Gynécologie - Obstétrique

Chirurgie vasculaire

Pneumologie

Anatomie et cytologie pathologique

Psychiatrie d'adultes

Pédiatrie

Pharmacologie

Histologie, Embryologie

Médecine et santé au travail

Pharmacologie

Hépatologie-Gastro-Entérologie

Hématologie

Neurologie

Psychiatrie d'adultes

Physiologie

Neurochirurgie

Psychiatrie d'adultes

Gynécologie - Obstétrique

Réanimation médicale

Neurochirurgie

Cardiologie 


\begin{tabular}{|c|c|c|}
\hline Mme & FAUVET Raffaèle & Gynécologie - Obstétrique \\
\hline M. & FISCHER Marc-Olivier & Anesthésiologie Réanimation et médecine Péri-opératoire \\
\hline M. & GÉRARD Jean-Louis & Anesthésiologie Réanimation et médecine Péri-opératoire \\
\hline M. & GUILLOIS Bernard & Pédiatrie \\
\hline Mme & GUITTET-BAUD Lydia & Epidémiologie, économie de la santé et prévention \\
\hline M. & HABRAND Jean-Louis & Cancérologie option Radiothérapie \\
\hline M. & HAMON Martial & Cardiologie \\
\hline Mme & HAMON Michèle & Radiologie et imagerie médicale \\
\hline M. & HANOUZ Jean-Luc & Anesthésiologie Réanimation et médecine Péri-opératoire \\
\hline M. & HULET Christophe & Chirurgie orthopédique et traumatologique \\
\hline M. & HURAULT de LIGNY Bruno Éméritat jusqu'au 31/01/2020 & Néphrologie \\
\hline M. & ICARD Philippe & Chirurgie thoracique et cardio-vasculaire \\
\hline M. & JOIN-LAMBERT Olivier & Bactériologie - Virologie \\
\hline Mme & JOLY-LOBBEDEZ Florence & Cancérologie \\
\hline M. & JOUBERT Michael & Endocrinologie \\
\hline Mme & KOTTLER Marie-Laure & Biochimie et biologie moléculaire \\
\hline M. & LAUNOY Guy & Epidémiologie, économie de la santé et prévention \\
\hline M. & LE COUTOUR Xavier & Epidémiologie, économie de la santé et prévention \\
\hline M. & LE HELLO Simon & Bactériologie-Virologie \\
\hline Mme & LE MAUFF Brigitte & Immunologie \\
\hline M. & LEPORRIER Michel Éméritat jusqu'au 31/08/2020 & Hématologie \\
\hline M. & LEROY François & Rééducation fonctionnelle \\
\hline M. & LOBBEDEZ Thierry & Néphrologie \\
\hline M. & MANRIQUE Alain & Biophysique et médecine nucléaire \\
\hline M. & MARCÉLLI Christian & Rhumatologie \\
\hline M. & MARTINAUD Olivier & Neurologie \\
\hline M. & MAUREL Jean & Chirurgie générale \\
\hline M. & MILLIEZ Paul & Cardiologie \\
\hline M. & MOREAU Sylvain & Anatomie/Oto-Rhino-Laryngologie \\
\hline M. & MOUTEL Grégoire & Médecine légale et droit de la santé \\
\hline M. & NORMAND Hervé & Physiologie \\
\hline M. & PARIENTI Jean-Jacques & Biostatistiques, info. médicale et tech. de communication \\
\hline M. & PELAGE Jean-Pierre & Radiologie et imagerie médicale \\
\hline Mme & PIQUET Marie-Astrid & Nutrition \\
\hline M. & QUINTYN Jean-Claude & Ophtalmologie \\
\hline M. & RAVASSE Philippe & Chirurgie infantile \\
\hline M. & REZNIK Yves & Endocrinologie \\
\hline M. & ROD Julien & Chirurgie infantile \\
\hline M. & ROUPIE Eric & Médecine d'urgence \\
\hline Mme & THARIAT Juliette & Radiothérapie \\
\hline M. & TILLOU Xavier & Urologie \\
\hline M. & TOUZÉ Emmanuel & Neurologie \\
\hline M. & TROUSSARD Xavier & Hématologie \\
\hline Mme & VABRET Astrid & Bactériologie - Virologie \\
\hline
\end{tabular}


M. VERDON Renaud

Mme VERNEUIL Laurence

M. VIADER Fausto

M. VIVIEN Denis
Maladies infectieuses

Dermatologie

Neurologie

Biologie cellulaire

\section{PROFESSEUR DES UNIVERSITÉS}

\section{PROFESSEUR ASSOCIÉ DES UNIVERSITÉS A TEMPS PLEIN}
M. VABRET François
Addictologie

\section{PROFESSEURS ASSOCIÉS DES UNIVERSITÉS A MI-TEMPS}
M. de la SAYETTE Vincent
Mme DOMPMARTIN-BLANCHÈRE Anne
Mme LESCURE Pascale
M. SABATIER Rémi

PRCE

Mme LELEU Solveig

\author{
Neurologie \\ Dermatologie \\ Gériatrie et biologie du vieillissement \\ Cardiologie
}

Anglais 


\title{
Année Universitaire 2018 / 2019
}

\author{
Doyen \\ Professeur Emmanuel TOUZÉ \\ Assesseurs \\ Professeur Paul MILLIEZ (pédagogie) \\ Professeur Guy LAUNOY (recherche) \\ Professeur Sonia DOLLFUS \& Professeur Evelyne EMERY ( $3^{\text {ème }}$ cycle) \\ Directrice administrative \\ Madame Sarah CHEMTOB
}

\section{MAITRES DE CONFERENCES DES UNIVERSITÉS - PRATICIENS HOSPITALIERS}

M. ALEXANDRE Joachim

Mme BENHAÏM Annie

M. BESNARD Stéphane

Mme BONHOMME Julie

M. BOUVIER Nicolas

M. COULBAULT Laurent

M. CREVEUIL Christian

M. DE BOYSSON Hubert

Mme DEBRUYNE Danièle Éméritat jusqu'au 31/08/2019

Mme DERLON-BOREL Annie Éméritat jusqu'au 31/08/2020

Mme DINA Julia

Mme DUPONT Claire

M. ÉTARD Olivier

M. GABEREL Thomas

M. GRUCHY Nicolas

M. GUÉNOLÉ Fabian

M. HITIER Martin

M. ISNARD Christophe

M. LEGALLOIS Damien

Mme LELONG-BOULOUARD Véronique

Mme LEPORRIER Nathalie Éméritat jusqu'au 31/10/2020

Mme LEVALLET Guénaëlle

M. LUBRANO Jean

M. MITTRE Hervé

M. REPESSÉ Yohann

M. SESBOÜÉ Bruno

M. TOUTIRAIS Olivier
Pharmacologie clinique

Biologie cellulaire

Physiologie

Parasitologie et mycologie

Néphrologie

Biochimie et Biologie moléculaire

Biostatistiques, info. médicale et tech. de communication

Médecine interne

Pharmacologie fondamentale

Hématologie

Bactériologie - Virologie

Pédiatrie

Physiologie

Neurochirurgie

Génétique

Pédopsychiatrie

Anatomie - ORL Chirurgie Cervico-faciale

Bactériologie Virologie

Cardiologie

Pharmacologie fondamentale

Génétique

Cytologie et Histologie

Chirurgie générale

Biologie cellulaire

Hématologie

Physiologie

Immunologie 


\section{MAITRES DE CONFERENCES ASSOCIÉS DES UNIVERSITÉS A MI-TEMPS}

Mme ABBATE-LERAY Pascale

M. COUETTE Pierre-André (fin 31/08/19)

M. LE BAS François (fin 31/08/19)

M. SAINMONT Nicolas (fin 31/08/19)

Mme NOEL DE JAEGHER Sophie (fin 31/08/2021)
Médecine générale

Médecine générale

Médecine générale

Médecine générale

Médecine générale 


\section{Remerciements}

A Hubert De Boysson, mon directeur de thèse mais bien plus que cela un ami. Merci pour tout, merci de m'avoir fait découvrir le monde du Horton, de m'avoir toujours soutenu dans ce projet et en plus d'avoir été un chef formidable d'avoir toujours été à mon écoute.

Au Pr Achille AOUBA, merci d'avoir accepté d'être le président de ce jury de thèse, de m'avoir toujours soutenu dans mes projets professionnels et d'avoir été une oreille attentive, c'est un grand honneur pour moi de travailler à tes cotés chaque jour.

A Nicolas MARTIN-SILVA, plus qu'un collègue tu as su me donner l'envie d'être interniste, je suis ravi de pouvoir continuer à travailler à tes cotés dans le futur et de continuer à partager ton goût prononcé pour les (bonnes) blagues.

A Samuel DESHAYES, pour ton soutien et ton amitié au quotidien, un grand merci d'avoir accepté d'être dans mon jury pour ce jour spécial, j'ai hâte de poursuivre l'aventure à tes côtés.

Au Pr Jean-Claude QUYNTIN, c'est un grand honneur pour moi que vous ayez accepté de juger mon travail et d'être parmi les membres du jury.

A mes parents qui m'ont toujours soutenu même avec la distance, si j'en suis là aujourd'hui c'est grâce à vous.

A mon frère Nicolas et ma sœur Néféret pour leur soutien.

A mes grands-parents que je n'ai malheureusement pas le temps de voir aussi souvent que je le voudrais mais qui me font le bonheur d'être présents physiquement ou bien de là-haut.

A Patrice, qui a su me donner goût à d'autre chose que la médecine et notamment aux boissons à base de raisins.

A la famille FOURNAISE, Luc et Elisabeth, Emilien et Elodie ainsi que leurs 3 enfants (dont un m'a rappelé que je ne serais jamais pédiatre) et Camille, qui me font le plaisir d'être présents pour ce jour si particulier.

A mes futurs collègues Jonathan et Gwenola avec qui je vais avoir l'honneur de continuer à travailler.

Aux infirmières de médecine interne et notamment ma seconde maman Isabelle.

Aux « ti' culs », Anne-Charlotte, Marie, Caroline, Annabel, Chloé, Mathieu et Maxime, vous êtes tellement débiles mais je vous aime!

A mes amis caennais, Quitterie, Clément, Amaury, Agnès, William et Cléa. 
A mes amis rémois de la faculté de médecine, Lulu, L'Ardennais, Timothésticule, Maguette, Elodie, Nacim, Estelle et Aurélie avec qui le contact reste malgré la distance, merci pour tous les moments passés ensembles, j'aimerais tellement qu'on se voit plus !

A Morgan, les années passent et rien ne change, merci pour ta psychanalyse lors de nos soirées à refaire le monde !

A mes amis du Lycée, en particulier Marion, Manon, Stella, Edouard, Simon et Cyril.

A mes co-internes de DES, Mathieu, Luca, Sophie, Cédric, Martin, Marine, Alex, MC qui sont devenus des amis au fil du temps, merci pour tous ces moments passés ensembles.

A mes collègues pneumologues, Hélène, Laure, Constance, Simon, Robinou, Boris et Lolo, merci pour votre accueil et pour tous ces souvenirs !

A mes co-internes de réanimation médicale, Kevin, Mathieu, Célia, Martin et Roxane merci pour tous les bons moments passés ensembles.

A mes « chefs » rencontrés au fils de mes différents stages qui m'ont tant appris et avec qui j'ai partagé de très bons moments en particulier Antoine, Manuel, Clémence, Jocelyn, Dr Sylvie DARGERE et monsieur le Pr VERDON.

A l'équipe médicale du service de médecine interne de Tenon qui m'ont accueilli pendant 6 mois, tout particulièrement au Dr Sophie GEORGIN-LAVIALLE et au Pr Gilles GRATEAU, un grand merci pour tout.

A mes co-internes de Tenon, Camille, Victoire, Louise, Tiphaine, Hélène, Rim, Samuel, Martin et Julien, merci d'avoir accueilli un « vieux provincial (et chauve en plus !)» parmi vous, merci pour tous ces souvenirs mémorables! A très vite peut-être autour d'un verre (juste un petit verre vite fait !), vous me manquerez c'est une certitude.

A Sarah, qui m'a suivi dans cette aventure caennaise et m'a toujours soutenu, quel bonheur d'être à tes côtés chaque jour, je t'aime ma marmotte. 



\section{Abréviations :}

Intravenous (IV); Giant cell arteritis (GCA); Large vessel vasculitis (LVV); American College of Rheumatology (ACR); Anterior ischemic optic neuropathy (AION); Central retinal artery occlusion (CRAO); Posterior ischemic optic neuropathy (PION); Glucocorticoids (GC); Temporal artery biopsies (TAB); Polymyalgia rheumatica (PMR) 
Table 1. Characteristics of GCA patients with ophthalmologic involvement and of GCA age- and sex-matched controls.

\begin{tabular}{|c|c|c|c|}
\hline & $\begin{array}{c}\text { Patients with } \\
\text { ophthalmologic } \\
\text { involvement } \\
(n=104)\end{array}$ & $\begin{array}{c}\text { Controls without } \\
\text { ophthalmologic } \\
\text { involvement } \\
(n=104)\end{array}$ & $\boldsymbol{p}$ \\
\hline \multicolumn{4}{|l|}{ Cardiovascular risk factors } \\
\hline Tobacco use & $27(26)$ & $19(18)$ & 0.18 \\
\hline Hypertension & $56(54)$ & $69(66)$ & 0.07 \\
\hline Dyslipidemia & $34(33)$ & 41 (39) & 0.31 \\
\hline Diabetes mellitus & $17(16)$ & $12(12)$ & 0.32 \\
\hline History of coronary disease & $13(13)$ & $14(14)$ & 0.83 \\
\hline History of strokes & $8(8)$ & $11(11)$ & 0.47 \\
\hline \multicolumn{4}{|l|}{ Clinical manifestations } \\
\hline Body Mass Index & $25.1[16.2-34.2]$ & 24 [16-36.8] & 0.10 \\
\hline Fever & $11(11)$ & $31(30)$ & 0.0006 \\
\hline Cranial manifestations & $104(100)$ & $90(87)$ & 0.0001 \\
\hline Headaches & $72(69)$ & $84(81)$ & 0.054 \\
\hline Scalp tenderness & $38(37)$ & 41 (39) & 0.67 \\
\hline Temporal artery abnormalities & $26(25)$ & $25(24)$ & 0.94 \\
\hline Jaw claudication & $45(43)$ & $37(36)$ & 0.26 \\
\hline Polymyalgia rheumatica & $41(39)$ & $58(56)$ & 0.02 \\
\hline Positive Histology & 79 (76) & $59(57)$ & 0.003 \\
\hline $\begin{array}{l}\text { Large vessel vasculitis on } \\
\text { imaging at GCA diagnosis }\end{array}$ & $8 / 55(15)$ & $15 / 65(23)$ & 0.24 \\
\hline \multicolumn{4}{|l|}{$\begin{array}{l}\text { Laboratory Tests } \\
\text { Labs }\end{array}$} \\
\hline $\mathrm{ESR}, \mathrm{mm}$ & 63 [16-130] & 67 [7-141] & 0.25 \\
\hline CRP, mg/L & $54[3-535]$ & $103[3-421]$ & 0.004 \\
\hline Hemoglobin, g/dL & $11.8[7.4-15.9]$ & $11[7.2-14.9]$ & 0.005 \\
\hline \multicolumn{4}{|l|}{ Treatment } \\
\hline Initial GC doses, mg/kg/day & $0.87[0.25-1.46]$ & $0.75[0.27-1.60]$ & 0.03 \\
\hline Duration of $\mathrm{GC}$, months & $42[0-170]$ & $28[1-206]$ & 0.16 \\
\hline Use of a GC-sparing agent & $7(7)$ & $19(18)$ & 0.01 \\
\hline \multicolumn{4}{|l|}{ Outcomes } \\
\hline Total follow-up, months & $42[0-170]$ & 54 [1-211] & 0.10 \\
\hline Relapse & $45(43)$ & $58(56)$ & 0.07 \\
\hline GC-dependence & $21(20)$ & $30(29)$ & 0.15 \\
\hline Discontinuation of GC & $50 / 86^{a}(58)$ & $67 / 87^{\mathrm{a}}(77)$ & 0.008 \\
\hline
\end{tabular}

Values are number (\%) or median [range]; GCA: giant cell arteritis; ESR: erythrocyte sedimentation rate; CRP: C-reactive protein; GC: Glucocorticoids

${ }^{\mathrm{a}}$ Data was not available in all patients. 
Table 2. Characteristics of 104 GCA patients with ophthalmologic involvement at onset and according to their evolution after treatment

\begin{tabular}{|c|c|c|c|c|}
\hline & $\begin{array}{c}\text { Total } \\
(n=104)\end{array}$ & $\begin{array}{c}\text { Progressed } \\
\text { to blindness } \\
(n=42)\end{array}$ & $\begin{array}{c}\text { Visual } \\
\text { improvement } \\
(n=62)\end{array}$ & $p$ \\
\hline \multicolumn{5}{|l|}{ Demographics } \\
\hline Female & $68(65)$ & $30(71)$ & $38(61)$ & 0.29 \\
\hline Age & 78 [52-90] & 79 [65-89] & $76[52-90]$ & 0.005 \\
\hline \multicolumn{5}{|l|}{ Cardiovascular risk factors } \\
\hline Tobacco use & $27(26)$ & $7(17)$ & $20(32)$ & 0.08 \\
\hline Hypertension & $56(54)$ & $29(69)$ & $27(44)$ & 0.09 \\
\hline Dyslipidemia & $34(33)$ & $15(36)$ & $19(31)$ & 0.59 \\
\hline Diabetes mellitus & $17(16)$ & $8(19)$ & $9(15)$ & 0.54 \\
\hline History of coronary disease & $13(13)$ & $6(14)$ & $7(11)$ & 0.65 \\
\hline History of strokes & $8(8)$ & $3(7)$ & $5(8)$ & 0.86 \\
\hline \multicolumn{5}{|l|}{ Clinical findings } \\
\hline Body Mass Index & $\begin{array}{l}25.1[16.2- \\
34.2]\end{array}$ & $\begin{array}{c}25.8[17.2- \\
33.6]\end{array}$ & $\begin{array}{c}24.2[16.2- \\
34.2]\end{array}$ & 0.50 \\
\hline Fever & $11(11)$ & $2(5)$ & $9(15)$ & 0.11 \\
\hline Cranial manifestations & $104(100)$ & $42(100)$ & $62(100)$ & - \\
\hline Headaches & $72(69)$ & $28(67)$ & $44(71)$ & 0.64 \\
\hline Scalp tenderness & $38(37)$ & $17(40)$ & $21(34)$ & 0.49 \\
\hline Jaw claudication & $45(43)$ & $15(36)$ & $30(48)$ & 0.20 \\
\hline \multicolumn{4}{|l|}{ Initial visual symptoms } & 0.16 \\
\hline Unilateral involvement & $71(68)$ & $28(67)$ & $43(69)$ & 0.77 \\
\hline Visual loss & $9(9)$ & $8(19)$ & $1(2)$ & 0.002 \\
\hline Amaurosis fugax & $19(18)$ & $2(5)$ & $17(27)$ & 0.003 \\
\hline Diplopia & $14(13)$ & $0(0)$ & $14(23)$ & 0.0009 \\
\hline Blurred vision & $62(60)$ & $32(76)$ & $30(48)$ & 0.005 \\
\hline \multicolumn{5}{|l|}{ Dilated Fundus photography } \\
\hline $\begin{array}{r}\text { Anterior ischemic optic } \\
\text { neuropathy }\end{array}$ & $47(45)$ & $35(83)$ & $12(19)$ & $<0.0001$ \\
\hline Central retinal artery occlusion & $15(15)$ & $6(15)$ & $9(16)$ & 0.92 \\
\hline $\begin{array}{r}\text { Posterior ischemic optic } \\
\text { neuropathy }\end{array}$ & $2(2)$ & $2(5)$ & $0(0)$ & 0.09 \\
\hline Normal & $38(37)$ & $2(5)$ & $36(58)$ & $<0.0001$ \\
\hline $\begin{array}{l}\text { Involvement of cranial } \\
\text { nerve III and/or VI }\end{array}$ & 0,1 & $0(0)$ & $8(14)$ & 0.01 \\
\hline Positive Histology & $79(76)$ & $35(83)$ & $44(71)$ & 0.15 \\
\hline $\begin{array}{l}\text { Large vessel vasculitis on } \\
\text { imaging } \\
\text { Laboratory tests }\end{array}$ & $8 / 55(15)$ & $4 / 22(18)$ & $4 / 33(12)$ & 0.53 \\
\hline & & & $51[16-130]$ & 0.19 \\
\hline CRP, $\mathrm{mg} / \mathrm{L}$ & $54[3-535]$ & $86[3-535]$ & $44[3-380]$ & 0.09 \\
\hline $\begin{array}{l}\text { Delay between } \\
\text { ophthalmologic signs and } \\
\text { treatment, in days }\end{array}$ & $2[1-60]$ & $1[1-30]$ & $3[1-60]$ & 0.06 \\
\hline $\begin{array}{l}\text { Pulses of IV } \\
\text { methylprednisolone }\end{array}$ & $59 / 100^{a}(59)$ & $32 / 41(78)$ & $27 / 59(46)$ & 0.001 \\
\hline
\end{tabular}

Values are number (\%) or median [range]; GCA: giant cell arteritis; ESR: erythrocyte sedimentation rate; CRP: C-reactive protein; IV: intravenous

${ }^{a}$ In 4 patients, the information regarding IV pulse was lacking. 
Table 3. Variables associated with definite blindness or important visual damage in GCA patients with visual symptoms in a uni- and multivariable analysis

\begin{tabular}{lcccc}
\hline \multicolumn{1}{c}{ Characteristics } & Univariate OR [95\% Cl] & $\mathbf{p}$ & $\begin{array}{c}\text { Multivariate OR } \\
{[95 \% \mathrm{Cl}]}\end{array}$ & $\mathbf{p}$ \\
\hline Age $>79^{\mathrm{a}}$ & $2.33[1.05-5.26]$ & 0.03 & & \\
Delay of GC initiation & $1.07[1.01-1.16]$ & 0.01 & \\
AION and/or CRAO & $33.42[8.99-218.6]$ & $<0.0001$ & $33.42[8.99-218.6]$ & $<0.0001$ \\
IV pulses of MP & $4.21[1.76-10.82]$ & 0.001 & \\
\hline 95\% Cl: 95\% & confidence interval; OR: & odds ratio; GCA: giant cell arteritis; GC: \\
glucocorticoids; AION: anterior ischemic optic neuropathy; CRAO: central retinal artery \\
occlusion; IV: intravenous; MP: methylprednisolone \\
a 79 is the median age of patients who kept a persisting blindness or important visual \\
damage
\end{tabular}


Figure 1. The link between visual symptoms, ophthalmologic diagnosis and visual outcomes in 104 patients with GCA-related ophthalmologic involvement

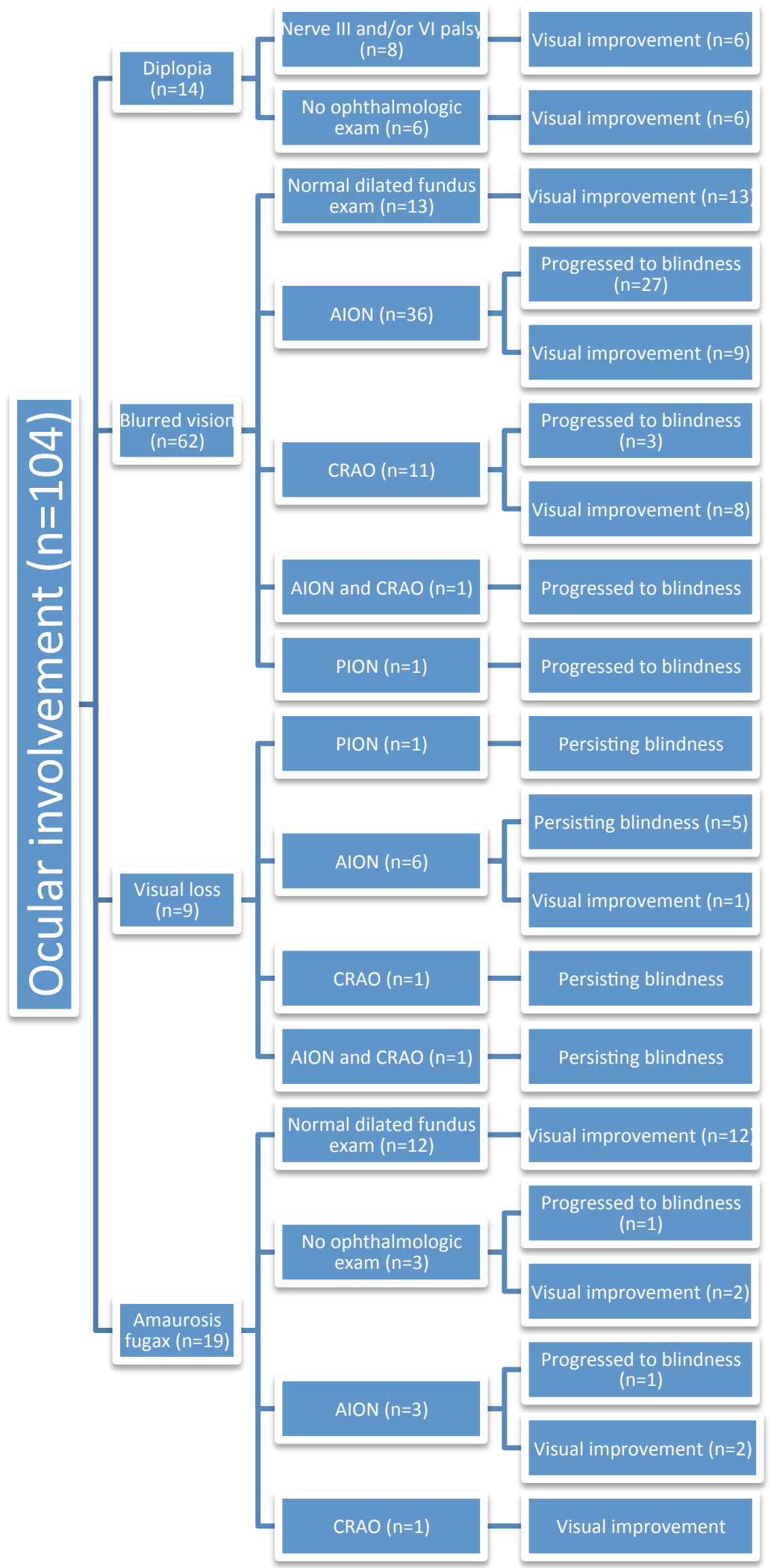

GCA: giant-cell arteritis; AION: anterior ischemic optic neuropathy; CRAO: central retinal artery occlusion; PION: posterior ischemic optic neuropathy. 
Supplemental table 1. Characteristics of the 137 eyes affected by GCA at disease onset and according to their evolution after treatment.

\begin{tabular}{|c|c|c|c|c|}
\hline & $\begin{array}{c}\text { Total of eyes } \\
\text { affected at } \\
\text { diagnosis } \\
n=137\end{array}$ & $\begin{array}{c}\text { Number of eyes } \\
\text { with persisting } \\
\text { blindness or that } \\
\text { progressed to } \\
\text { blindness after } \\
\text { initial treatment } \\
n=56\end{array}$ & $\begin{array}{c}\text { Number of eyes with } \\
\text { visual improvement } \\
\text { after initial treatment } \\
n=81\end{array}$ & $p$ \\
\hline \multicolumn{5}{|l|}{ Initial visual symptoms } \\
\hline Bilateral involvement & $66(48)$ & $28(50)$ & $38(47)$ & 0.72 \\
\hline $\begin{array}{l}\text { Diplopia } \\
\text { One eye } \\
\text { Both eves }\end{array}$ & $\begin{array}{c}19(14) \\
9 \\
5 \times 2\end{array}$ & $\begin{array}{l}0(0) \\
- \\
-\end{array}$ & $\begin{array}{c}19(23) \\
9 \\
5 \times 2\end{array}$ & $<0.0001$ \\
\hline Amaurosis fugax & $22(16)$ & $3(5)$ & $19(23)$ & 0.005 \\
\hline One eye & 16 & 1 & 15 & \\
\hline Both eyes & $3 \times 2$ & $1 \times 2$ & $2 \times 2$ & \\
\hline Visual loss & $14(10)$ & $13(23)$ & $1(1)$ & $<0.0001$ \\
\hline One eye & 4 & 3 & 1 & \\
\hline Both eyes & $5 \times 2$ & $5 \times 2$ & - & \\
\hline Blurred vision & $82(60)$ & $40(71)$ & $42(52)$ & 0.02 \\
\hline One eye & 42 & 24 & 18 & \\
\hline \multirow{2}{*}{\multicolumn{5}{|c|}{ Dilated fundus photography }} \\
\hline & & & & \\
\hline $\begin{array}{r}\text { Anterior ischemic optic } \\
\text { neuropathy }\end{array}$ & $60(44)$ & $47(84)$ & $13(16)$ & $<0.0001$ \\
\hline $\begin{array}{r}\text { Central retinal artery } \\
\text { occlusion }\end{array}$ & $15(11)$ & $6(11)$ & $9(11)$ & 0.9 \\
\hline $\begin{array}{r}\text { Posterior ischemic optic } \\
\text { neuropathy }\end{array}$ & $2(1)$ & $2(4)$ & $0(0)$ & 0.09 \\
\hline $\begin{array}{l}\text { Involvement of cranial } \\
\text { nerve III and/or VI }\end{array}$ & $11(8)$ & $0(0)$ & $11(14)$ & $<0.0001$ \\
\hline
\end{tabular}

Values are number (\%) 



\section{Sommaire}

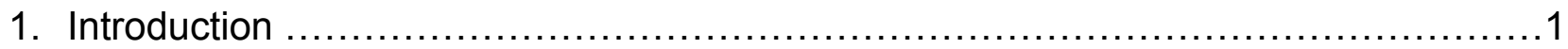

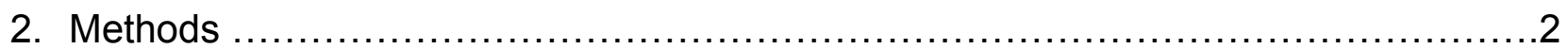

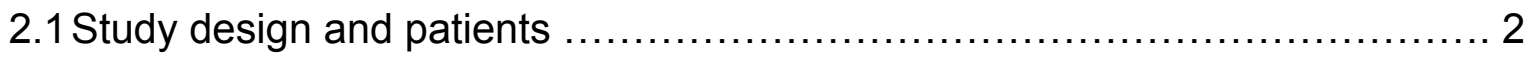

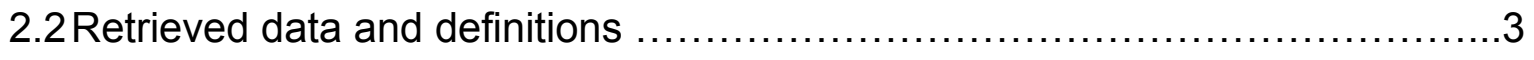

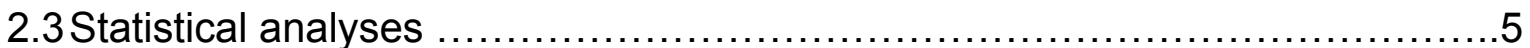

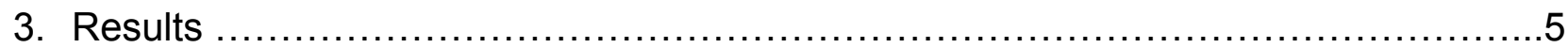

3.1 Description of patients with ophthalmologic manifestations and controls .......5

3.2Outcomes under treatment and differences according to the ophthalmologic

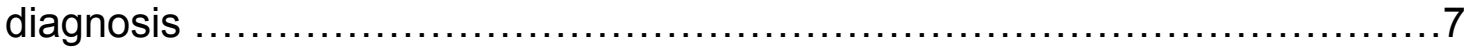

3.3Description of patients with bilateral ophthalmologic involvement at diagnosis..9

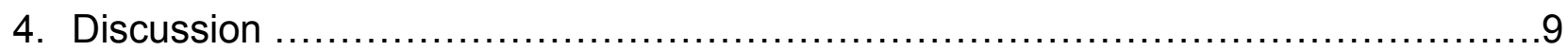

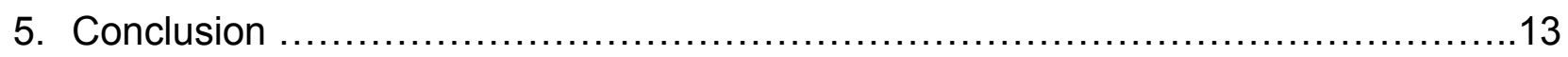




\section{INTRODUCTION}

Giant-cell arteritis (GCA) is the most frequent form of vasculitis in patients over 50 years old. Involvement of cranial vessels, especially from the internal carotid, exposes patients to ischemic complications, such as visual impairment or stroke. Ophthalmologic manifestations include different symptoms from transient visual loss or blurred vision to definite blindness, affecting one or two eyes. Typically, visual symptoms are linked to the inflammatory involvement of the ophthalmologic arteries and their branches, especially the posterior ciliary arteries and the central retinal artery, leading to acute anterior ischemic optic neuropathy (AION) or central retinal artery occlusion (CRAO), respectively. More rarely, visual impairment is linked to III or VI nerves' palsy or posterior ischemic optic neuropathy (PION). As soon as a GCA diagnosis is presumed in a patient with visual symptoms, glucocorticoids (GC) have to be started often with intravenous pulses of methylprednisolone with the aim to improve visual function and avoid involvement of the contralateral eye and the occurrence of a new ischemic event. The more common and faster use of GC as well as higher physician awareness of GCA ischemic complications led to a decrease of definite blindness rates from $70 \%$ to less than $10 \%$ in some studies $[1,2,3,4]$.

Most studies dealing with ophthalmologic involvement in GCA describe selected patients or small series with $<100$ patients [5-12]. Moreover, the link between visual symptoms described by patients and the ophthalmologic diagnosis is poorly studied. In this study, we retrospectively analyzed ophthalmologic involvement in a monocentric cohort of consecutive GCA patients. Each ophthalmologic diagnosis was reassessed by an ophthalmologist. Characteristics and outcomes of patients with ophthalmologic involvement were analyzed and compared with age- and sex-matched controls without such involvement. We specifically analyzed the outcomes of patients according to the different ophthalmologic diagnoses and the therapeutic regimens they received, especially the impact of intravenous pulses of methylprednisolone. 


\section{METHODS}

\subsection{Study design and patients}

In this monocentric retrospective study, we included all consecutive patients diagnosed with GCA-related ophthalmologic involvement between 2000 and 2016 in a department of Internal Medicine in a tertiary hospital in Western France. Patients were retrieved in a database of 409 patients diagnosed consecutively with GCA and followed up in our center. This database enrolled patients identified via the centralized hospital diagnostic database via the department of histology where temporal artery biopsies (TAB) were analyzed and via the department of Ophthalmology.

In all patients, the GCA diagnosis was retained based on the presence of at least 3 criteria from the American College of Rheumatology (ACR) [13] or 2 ACR criteria associated with large-vessel vasculitis (LVV), which was demonstrated by imaging or biopsy-proven giant-cell vasculitis on an extratemporal vascular sample.

Data of the 409 patients are collected in a centralized database that was previously described [14-16]. We retrieved all GCA patients with visual symptoms at diagnosis from the cohort and compared them to age- and sex-matched GCA control patients without visual symptoms. We chose to compare patients to matched controls and not to the remaining patients from the cohort in order to avoid an overrepresentation of the control group. Moreover, given that many studies, including ours [17, 18], showed an older age of patients with cranial ischemic symptoms, we aimed to limit the influence of age in the comparison of patients.

This study was conducted in compliance with good clinical practices and the Declaration of Helsinki principles. In accordance with French public health law (Art. L 11211-1, Art. L 1121-1-2), written consent from the patient is not required for this type of 
retrospective study. Our local ethics committee confirmed the observational noninterventional retrospective nature of our cohort.

\subsection{Retrieved data and definitions}

For all included patients and controls, we collected demographics, body mass index (BMI), cardiovascular risk factors (tobacco use, diabetes mellitus, dyslipidemia, hypertension, previous coronary disease or stroke), laboratory tests (including erythrocyte sedimentation rate (ESR), c-reactive protein (CRP), hemoglobin and platelet levels), TAB status, the results of another vascular sample when available, and the results of imaging searching for an LVV in patients who performed the procedure. Many patients undergo large-vessel imaging in our center as a systematic research of LVV regardless of whether they complained of large-vessel symptoms.

Cranial manifestations included headaches, temporal artery pulse absence, jaw claudication, scalp tenderness and visual symptoms. Extracranial symptoms include polymyalgia rheumatica (PMR) and peripheral vascular signs (pulseless limb, peripheral vascular bruits).

Each ophthalmologic medical file was reanalyzed by an ophthalmologist $(A L)$, especially fundus photography and fluorescein angiography when available.

We distinguished four different visual clinical symptoms described by patients before GCA diagnosis: visual loss (i.e., total absence of visual perception, or difficulties counting fingers or distinguishing hand motion or light perception at the first examination, or also defined by a visual acuity $<1 / 20$ if this data was available), amaurosis fugax (defined as transient visual loss lasting $<1$ hour), diplopia and blurred vision (defined as reduced vision that did not satisfy the definition of visual loss).

Ophthalmologic diagnoses reassessed by our ophthalmologist included AION when fundus photography showed an optic disc edema (unilateral or bilateral) +/- with peri- 
papillary splinter hemorrhage and CRAO when fundus photography showed the occlusion of the central retinal artery +/- with a "cherry red spot" in the macula or with an ischemic retinal whitening. PION was retrospectively diagnosed based on the presence of persistent visual impairment and a fundus showing an optic atrophy at distance while the first fundus was initially normal. Cranial nerve palsy was diagnosed upon clinical examination. When performed, we recorded the results of the fluorescein angiography. A delay of perfusion or a hypoperfusion of the choroid retina on angiography were suggestive of choroidal ischemia and especially an AION when other cranial GCA-related signs existed or when acute phase reactants were increased. AION and CRAO corresponded to ophthalmologic ischemic involvements.

We defined important visual damage as vision precluding any use of the affected eye in daily activities. We defined visual improvement as sufficient vision improvement allowing the patient to use the affected eye in daily activities (reading, driving,....).

Treatments regimen were collected, especially the GC management, including starting doses, the use of IV pulses before oral route and treatment durations.

We analyzed the rate of relapse defined on the association of 1) a reoccurrence of clinical symptoms attributable to GCA or PMR; 2) an increase of acute phase reactants; 3) a favorable response to an increase or a change of GCA-related treatment(s) and 4) the absence of another cause identified. GC dependence was defined on the presence of $\geq 2$ relapses and at least 2 of the following criteria: 1) a daily dose of oral prednisone $>20$ $\mathrm{mg} /$ day (or $0.30 \mathrm{mg} / \mathrm{kg}$ ) at 6 th month; 2) a daily dose of oral prednisone $>10 \mathrm{mg} /$ day (or 0.20 $\mathrm{mg} / \mathrm{kg}$ ) at 12 th month; 3) a treatment maintained $>24$ months due to a relapsing disease course.

GC discontinuation rate and the use of immunosuppressants were also noted. Regarding ophthalmologic outcomes, we analyzed whether treatment improved visual function and whether damage remained at last follow-up. Permanent visual loss corresponded to definite unilateral or bilateral blindness. 


\subsection{Statistical analyses}

Categorical variables were expressed as the number (\%) and quantitative variables as median (range). Categorical variables were analyzed using the Chi-square or Fisher's exact test, and quantitative variables were analyzed using the Mann-Whitney test.

A logistic regression model was used to assess predictive factors associated with definite blindness. Odds ratios (ORs) and 95\% confidence intervals (Cl) were computed for each predictor in the univariate analysis and the multivariable model using the backward stepwise approach using variables that reached $p<0.1$ in univariate analyses.

The statistical analyses were computed using JMP 9.0.1 (SAS Institute Inc., Cary, NC, USA). A $p \leq 0.05$ defined statistical significance.

\section{RESULTS}

\subsection{Description of patients with ophthalmologic manifestations and controls}

Among the 409 patients from the cohort, 104 (25\%) patients presented visual symptoms at GCA diagnosis.

The detailed characteristics of the 104 patients with visual symptoms and the 104 controls are shown and compared in Table 1. Compared with controls, patients with visual symptoms at GCA diagnosis showed less frequent fevers ( $11 \%$ versus $30 \% ; p=0.0006)$, less PMR $(39 \%$ versus $56 \% ; p=0.02)$ and lower inflammatory parameters on laboratory tests, including lower CRP level (median: 54 [3-535] mg/L versus 103 [3-421] mg/L, $p=0.004$ ) and higher hemoglobin level (median of $11.8[7.4-15.9] \mathrm{g} / \mathrm{dL}$ versus 11 [7.2-14.9] $\mathrm{g} / \mathrm{dL}, p=0.005$ ). Conversely, patients showed more cranial manifestations (100\% versus $87 \% ; p=0.0001)$ and more positive $\operatorname{TAB}(76 \%$ versus $57 \% ; p=0.003)$ than controls. 
Visual symptoms are detailed in Table 2 and were unilateral in $71(68 \%)$ patients and bilateral in the remaining $33(32 \%)$. Blurred vision was the most frequent visual symptom affecting $62(60 \%)$ patients. In patients with visual loss or blurred vision at diagnosis, 24 $(34 \%)$ patients presented transient visual symptoms in the few days before diagnosis.

Four (4\%) patients presented a concomitant stroke at diagnosis along with visual symptoms, and only one had an ischemic stroke in occipital area but with a fundus exam showing a CRAO.

A dilated fundus photography was performed in $98(94 \%)$ patients. AION was the ophthalmologic diagnosis more frequently observed in 47 (45\%) patients followed by CRAO in $15(15 \%)$. Two patients presented a CRAO on one eye and an AION on the other. In 38 (39\%) patients, fundus photography was normal. Two (2\%) patients with an initially normal fundus were further diagnosed with a PION on a second fundus performed few days after due to persisting blindness. The 6 patients who did not undergo fundus photography complained of diplopia ( 3 patients) and amaurosis fugax (3 patients). They were admitted from a peripheral hospital and immediately received GC treatment without ophthalmologic exam before being admitted in our department. Finally, $8(8 \%)$ patients had III or VI nerve palsy, and a normal fundus was noted in all patients.

Among the patients who presented AION at diagnosis, fluorescein angiography was performed in $23(50 \%)$, which showed a perfusion delay in $15(65 \%)$ of them. Thirteen $(28 \%)$ patients with AION presented a bilateral involvement. Both eyes were affected at diagnosis in 9 , whereas the 4 others presented the same lesion on the contralateral eye few days later while the treatment was initiated. Among these 4 patients, GC was initiated at a median delay of 3 [1-7] days after symptom onset, and 3 received IV pulses of methylprednisolone.

The link between visual symptoms and the ophthalmologic diagnosis is shown in Figure 1. 


\subsection{Outcomes under treatment and differences according to the ophthalmologic diagnosis}

In Supplemental Table 1, we separately analyzed the 137 eyes affected by GCA as well as their outcomes with treatment.

Regarding treatment, patients with visual symptoms received significantly higher doses of GC at initiation $(0.87[0.25-1.46] \mathrm{mg} / \mathrm{kg} /$ day versus $0.75[0.27-1.60] \mathrm{mg} / \mathrm{kg} / \mathrm{day}$ in controls; $p=0.03)$. Moreover, intravenous methylprednisolone pulses were coadministered in $59 \%$ of patients with visual symptoms and none of the controls $(p<0.00001)$. At last followup, more controls had discontinued the treatment $(p=0.008)$. In all patients who discontinued GC, treatment duration was not different in both groups. Relapse and GC-dependence rates were not different in patients with visual symptoms and controls, but more controls received an immunosuppressant as a GC-sparing agent $(p=0.01)$. Of note, no patients showed visual symptoms at relapse.

The delay between the first visual symptoms and GC initiation was 2 [1-60] days. The evolution of patients with visual symptoms revealed a visual improvement in 62 (60\%) patients and unilateral (in 31 patients) or bilateral (in 11 patients) definite blindness/important visual damage in the remaining $42(40 \%)$. Table 2 showed the comparison between patients who had a visual improvement and those who progressed to definite blindness or important visual damage. Progression to blindness was significantly more frequent in older patients (median age: 79 [65-89] years in patients with definite blindness versus 76 [52-90] years in patients with visual improvement; $p=0.005$ ). Definite blindness or visual damage was more frequently observed in patients with initial visual loss (8 (19\%) patients with definite blindness versus $1(2 \%)$ patient with visual improvement; $p=0.0006)$ and initial blurred vision $(32(76 \%)$ patients with definite blindness versus $30(48 \%)$ patients with visual improvement; $p=0.005)$. Conversely, amaurosis fugax (1 (2\%) patient with definite blindness versus $18(29 \%)$ 
patients with visual improvement; $p=0.0006$ ) and diplopia (no patient with definite blindness versus $14(23 \%)$ patients with visual improvement; $p=0.0009)$ were significantly more frequently observed in patients with total visual improvement.

Regarding the ophthalmologic diagnosis, AION was more frequently associated with definite blindness or important visual damage than with visual improvement. Among the 47 patients with AION, 35 (83\%) patients had definite blindness or important visual damage, whereas only $12(19 \%)$ experienced a visual improvement $(p<0.0001)$. Among the 60 patients who exhibited an initial ophthalmologic ischemic involvement, i.e., an AION and/or a CRAO, definite blindness or important visual damage was maintained in $39(65 \%)$, although $45(75 \%)$ received IV pulses.

The delay of GC initiation was not significantly different in patients with and without visual improvement (3 [1-60] days in patients with visual improvement versus 1 [1-30] days in patients with definite blindness; $p=0.06$ ). More patients with definite blindness or important visual damage received IV methylprednisolone pulses $(78 \%$ versus $46 \%$ in patients with visual improvement; $p=0.001$ ).

Once GC started, a total of 4 (4\%) previously described patients experienced a new ischemic ophthalmologic event, namely, an AION affecting the second eye; however, 3 of them received IV pulses at 1,5 and 7 days after symptom onset.

All patients with visual symptoms received acetylsalicylic acid (ASA) at diagnosis (94 patients $(90 \%))$; the remaining 10 patients $(10 \%)$ were already treated with Vitamin-K antagonists or direct oral anticoagulant.

Table 3 presents the factors potentially associated with definite blindness as assessed by a uni- and multivariate model. Ischemic ophthalmologic lesions, i.e., AION or CRAO, were the single factors that were associated with a definite blindness (95\% confidence interval, odds ratio: 33.42 [8.99—218.6], $p<0.0001)$. 


\subsection{Description of patients with bilateral ophthalmologic involvement at diagnosis}

Among the 33 patients who experienced bilateral ophthalmologic involvement, 13 (39\%) presented bilateral AION, $2(6 \%)$ presented AION in one eye and CRAO in second eye, and bilateral cranial nerve palsy was observed in $3(9 \%)$ patients. Thirteen patients (39\%) did not have any ophthalmologic diagnosis despite a bilateral examination, and 2 (6\%) patients, including one with bilateral diplopia and another with bilateral amaurosis fugax, did not have any ophthalmologic examination.

Among the 33 patients with bilateral involvement, 12 (36\%) maintained bilateral blindness, $2(6 \%)$ had a unilateral improvement and $19(58 \%)$ had a total bilateral improvement. The 12 patients with persisting bilateral blindness initially showed AION in 22 eyes and CRAO in 2, and $21(64 \%)$ received methylprednisolone IV pulses. The 2 patients with unilateral improvement initially had AION in both eyes, and they both received IV pulses. Finally, the 19 patients with a total bilateral improvement showed initially a bilateral AION in 1, a bilateral nerve palsy in 3, and no ophthalmologic diagnosis in the other. Eight (42\%) of them received IV pulses.

\section{DISCUSSION}

Ophthalmologic involvement is frequent in GCA and was observed in one-quarter of all our patients. Despite a prompt diagnosis and initiation of treatment, $40 \%$ of our patients with visual symptoms did not recover their vision, and $10 \%$ of them remained bilaterally blind. Altogether, the global rate of blindness (affecting one or two eyes) in our cohort is $10 \%$, which is concordant with other studies $[10,11,19]$. A new ischemic event (AION in all cases) occurred in $5 \%$ of patients with visual symptoms despite the initiation of treatment, including methylprednisolone pulses in four of them. 
Our study provided a relevant analysis of the GCA-related ophthalmologic involvement and focused on the link between the visual signs described by the patient and the ophthalmologic diagnosis.

AION was the ophthalmologic diagnosis the more frequently observed in half of our patients with visual symptoms and in three-quarters of patients who were admitted with persistent visual impairment (visual loss or blurred vision), which is concordant with other studies [5-7, 11, 12, 20]. Indeed, Gonzalez-Gay et al. [12], observed AION in 22 patients out of 24 with visual loss; Liozon et al. [8], in 20 out of 23; and Chen et al. [5] in 85\% of patients with permanent visual loss.

Patients with visual symptoms showed some particular characteristics at diagnosis compared with controls, namely, less PMR, less fever and lower acute phase reactants. These results are in accordance with other studies $[5,9,10,12]$.

As observed in another study [21], we also found more biopsy-proven GCA in patients with visual symptoms.

Atherosclerosis remains the main differential diagnosis in a patient with an ischemic ophthalmologic complication, especially in CRAO. The study of Yates et al. [19] showed that in the setting of GCA, a history of cerebrovascular accident and peripheral vascular disease was associated with blindness at 6 months, suggesting the possible participation of atherosclerosis in the occurrence of the ophthalmologic event. The possible link between atherosclerosis and ocular manifestations was also suggested in another GCA populationbased study showing that permanent visual loss and arterial hypertension were predictive factors of stroke [18]. In contrast, we did not observe cardiovascular risk factors or previous cardiovascular diseases as risk factors for visual involvement in GCA. However, we observed that patients who progressed to blindness were older than those with an improvement of vision, suggesting a possible impact of atherosclerosis, which is probably more frequent in older patients. Moreover, in this study, we did not analyze the impact of 
cardiovascular treatments, such as statins, but all patients in this cohort had a concomitant prescription of aspirin or anticoagulant treatment.

A study from Lopez-Diaz et al suggested an association between a high ESR level at diagnosis and the risk of developing visual ischemic manifestations and permanent visual loss [22]. We did not observe higher acute phase reactant levels at diagnosis in our patients who stayed visually impaired, but other studies are required to more extensively analyze the link between systemic inflammation and ischemic events.

To date, the best management of GCA-related ophthalmologic involvement remains the prompt prescription of high GC doses, and the first-line use of IV pulses is often in accordance with different guidelines, such as the French or British recommendations [23, 24]. However, our results and other studies did not indicate a better effect of IV pulses compared with oral administration in preventing further visual loss [25, 26]. In addition, patients with AION particularly experienced poor outcomes without visual improvement, although they more likely received IV pulses. In this setting, the use of GC is probably insufficient to stop or reverse the ischemic process. Further studies with the adjunction of other drugs, especially tocilizumab, are expected with the hope to improve the visual prognosis in patients with AION. Altogether, our results did not suggest a good improvement of vision under GC in patients with initial ischemic ophthalmologic involvement, i.e., AION or CRAO. Furthermore, despite treatment initiation, 4 (4\%) patients presented a new ischemic ophthalmologic event affecting the second eye. However, in these 4 patients, one did not receive IV pulses, and two others had a delay of initiation of GC treatment at five and seven days, separately. In the literature, 1 to $4 \%$ of patients experience a new ischemic event despite GC therapy, which is concordant with our results [8, 26].

Some studies showed that the presence of transient cranial manifestations before treatment initiation was associated with the development of ischemic complications and permanent visual loss $[6,8,10]$. In our study, $44 \%$ of patients with visual loss at diagnosis presented a transient visual symptom before treatment initiation, which is concordant with 
the literature where 32 to $58 \%$ of patients experienced previous transient visual symptoms $[6,8,10]$.

Altogether, these results support maximal and early identification of GCA-related ophthalmic involvement to start GC therapy as early as possible. Hocevar et al. [27] showed that permanent visual loss was more common in late-diagnosed GCA. Laskou et al. [28] developed a probability score to aid the diagnosis of GCA for generalist physicians to start GC therapy promptly. The need of an early GCA diagnosis led to the development of fast track strategies [29, 30]. Diamantopolous et al. [29] showed an $88 \%$ lower risk of permanent visual loss in GCA patients examined through a fast-track ultrasound clinic compared with a control group conventionally assessed; only one patient in the fast-track strategy experienced a permanent visual loss versus 6 patients in the conventional group. In another study from Patil et al. [30] a reduction of irreversible visual loss from $37 \%$ to $9 \%$ was observed with a fast track pathway.

Some limitations should be discussed in this study. First, the retrospective design limits the completeness of data retrieval. Furthermore, $7 \%$ of our patients did not have an ophthalmologic exam at diagnosis and were treated immediately with GC.

Second, initial clinical visual symptoms described by patients and visual outcomes were subjective, based on patients' appreciations. The absence of visual acuity or visual field testing at diagnosis and during follow-up is an important limitation, mainly due to the retrospective design and because many of our patients are addressed and followed-up by non-hospital ophthalmologists. However, this also reflects real-life practices in a French GCA referral department of internal medicine. Visual acuity testing information is mainly used by ophthalmologists and is not used to guide the diagnosis and therapeutic strategy. Given the absence of consensual recommendations regarding GC tapering and the use of IV pulses, differences regarding GC management exist within the cohort. Indeed, the initial treatment was at the discretion of each physician in charge of the patient. 


\section{CONCLUSION}

In conclusion, GCA-related ophthalmologic involvement affected one-quarter of patients in this monocentric cohort of consecutive patients, and $10 \%$ did not recover their vision. These data confirm and encourage the need to develop fast-track strategies to prevent these ophthalmologic complications that are often irreversible. AOIN remained the most frequent ophthalmologic diagnosis with the poorer outcomes despite GC IV pulses. Further prospective studies are therefore required to improve specific outcomes in such patients, and new therapeutic strategies using available biotherapies, such as tocilizumab, are awaited. 


\section{Bibliographie :}

[1]. Bengtsson BA, Malmvall BE. The epidemiology of giant cell arteritis including temporal arteritis and polymyalgia rheumatica. Incidences of different clinical presentations and eye complications. Arthritis Rheum. 1981;24:899-904.

[2]. Vodopivec I, Rizzo JF, 3rd. Ophthalmic manifestations of giant cell arteritis. Rheumatology (Oxford). 2018;57:63-72.

[3]. Gonzalez-Gay MA, Miranda-Filloy JA, Lopez-Diaz MJ, et al. Giant cell arteritis i northwestern Spain: a 25-year epidemiologic study. Medicine (Baltimore). 2007;86:61-8.

[4] Gonzalez-Gay MA, Castaneda S, Llorca J. Giant Cell Arteritis: Visual loss is our major concern. J Rheumatol. 2016;43:1458-61.

[5]. Chen JJ, Leavitt JA, Fang C, Crowson CS, Matteson EL, Warrington KJ. Evaluating the incidence of arteritic ischemic optic neuropathy and other causes of vision loss from giant cell arteritis. Ophthalmology. 2016;123:1999-2003.

[6]. Hayreh SS, Podhajsky PA, Zimmerman B. Ocular manifestations of giant cell arteritis. Am J Ophthalmol. 1998;125:509-520.

[7]. Danesh-Meyer H, Savino PJ, Gamble GG. Poor prognosis of visual outcome after visual loss from giant cell arteritis. Ophthalmology. 2005;112:1098-1103.

[8]. Liozon E, Herrmann F, Ly K, et al. Risk factors for visual loss in giant cell (temporal) arteritis: a prospective study of 174 patients. Am J Med. 2001;111:211-217.

[9]. Salvarani C, Cimino L, Macchioni P, et al. Risk factors for visual loss in an Italian population-based cohort of patients with giant cell arteritis. Arthritis Rheum. 2005;53:293-297.

[10]. Cid MC, Font C, Oristrell J, et al. Association between strong inflammatory response and low risk of developing visual loss and other cranial ischemic complications in giant cell (temporal) arteritis. Arthritis Rheum. 1998;41:26-32. 
[11]. Singh AG, Kermani TA, Crowson CS, Weyand CM, Matteson EL, Warrington KJ. Visual manifestations in giant cell arteritis: trend over 5 decades in a population-based cohort. J Rheumatol. 2015;42:309-315.

[12]. Gonzalez-Gay MA, Garcia-Porrua C, Llorca J, et al. Visual manifestations of giant cell arteritis. Trends and clinical spectrum in 161 patients. Medicine (Baltimore). 2000;79:283-292.

[13]. Hunder GG, Bloch DA, Michel BA, et al. The American college of rheumatology 1990 criteria for the classification of giant cell arteritis. Arthritis Rheum. 1990;33:1122-1128.

[14]. De Boysson H, Liozon E, Ly KH, et al. Giant cell arteritis presenting as isolated inflammatory response and/or fever of unknown origin: a case-control study. Clin Rheumatol. 2018;37:3405-3410.

[15]. De Boysson H, Daumas A, Vautier M, et al. Large-vessel involvement and aortic dilation in giant-cell arteritis. A multicenter study of 549 patients. Autoimmun Rev. 2018;17:391-398.

[16]. Dumont A, Parienti JJ, Delmas C, et al. Factors associated with relapse and dependence to glucocorticoids in giant-cell arteritis. J Rheumatol. 2019;181127. doi: 10.3899/jrheum.181127

[17]. De Boysson H, Liozon E, Lariviere D, et al. Giant cell arteritis-related stroke: a retrospective multicenter case-control study. J Rheumatol. 2017;44:297-303.

[18]. Gonzalez-Gay MA, Vazquez-Rodriguez TR, Gomez-Acebo I, et al. Strokes at time of disease diagnosis in a series of 287 patients with biopsy-proven giant cell arteritis. Medicine (Baltimore). 2009;88:227-235.

[19]. Yates M, MacGregor AJ, Robson J, et al. The association of vascular risk factors with visual loss in giant cell arteritis. Rheumatology (Oxford). 2017;56:524-528.

[20]. Liu GT, Glaser JS, Schatz NJ, Smith JL. Visual morbidity in giant cell arteritis. Clinical characteristics and prognosis for vision. Ophthalmology. 1994;101:1779-1785. 
[21]. Gonzalez-Gay MA, Garcia-Porrua C, Llorca J, Gonzalez-Louzao C, Rodriguez-Ledo P. Biopsy-negative giant cell arteritis: clinical spectrum and predictive factors for positive temporal artery biopsy. Semin Arthritis Rheum. 2001;30:249-56.

[22]. Lopez-Diaz MJ, Llorca J, Gonzalez-Juanatey C, Pena-Sagredo JL, Martin J, Gonzalez-Gay MA. The erythrocyte sedimentation rate is associated with the development of visual complications in biopsy-proven giant cell arteritis. Semin Arthritis Rheum. 2008;38:116-23.

[23]. Bienvenu B, Ly KH, Lambert $\mathrm{M}$, et al. Management of giant cell arteritis: recommendations of the French study group for large vessel vasculitis (GEFA). Rev Med Interne. 2016;37:154-165.

[24]. Dasgupta B, Borg FA, Hassan N, et al. BSR and BHPR guidelines for the management of giant cell arteritis. Rheumatology (Oxford). 2010;49:1594-1597.

[25]. Hayreh SS, Zimmerman B, Kardon RH. Visual improvement with corticosteroid therapy in giant cell arteritis. Report of a large study and review of literature. Acta Ophthalmol Scand. 2002;80:355-367.

[26]. Hayreh SS, Zimmerman B. Visual deterioration in giant cell arteritis patients while on high doses of corticosteroid therapy. Ophthalmology. 2003;110:1204-1215.

[27]. Hocevar A, Rotar Z, Jese R, et al. Do early diagnosis and glucocorticoid treatment decrease the risk of permanent visual loss and early relapses in giant cell arteritis: a prospective longitudinal study. Medicine (Baltimore). 2016;95:e3210.

[28]. Laskou F, Coath F, Mackie SL, Banerjee S, Aung T, Dasgupta B. A probability score to aid the diagnosis of suspected giant cell arteritis. Clin Exp Rheumatol. 2019 Feb 15. [Epub ahead of print].

[29]. Diamantopoulos AP, Haugeberg G, Lindland A, Myklebust G. The fast-track ultrasound clinic for early diagnosis of giant cell arteritis significantly reduces permanent visual impairment: towards a more effective strategy to improve clinical outcome in giant cell arteritis? Rheumatology (Oxford). 2016;55:66-70. 
[30]. Patil P, Williams M, Maw WW, et al. Fast track pathway reduces sight loss in giant cell arteritis: results of a longitudinal observational cohort study. Clin Exp Rheumatol. 2015;33:S-103-106. 
Annexes 
"Par délibération de son Conseil en date du 10 Novembre 1972, l'Université n'entend donner aucune approbation ni improbation aux opinions émises dans les thèses ou mémoires. Ces opinions doivent être considérées comme propres à leurs auteurs ". 
VU, le Président de Thèse

VU, le Doyen de la Faculté

VU et permis d'imprimer

en référence à la délibération

du Conseil d'Université

en date du 14 Décembre 1973

Pour le Président

de l'Université de CAEN et P.O

Le Doyen 
TITRE DE LA THESE : Caractéristiques et évolution des manifestations ophtalmologiques dans l'artérite à cellules géantes : une étude cas-témoin.

RESUME DE LA THESE EN FRANÇAIS :

Objectif: Décrire les caractéristiques et l'évolution des manifestations ophtalmologiques au diagnostic dans l'artérite à cellules géantes (ACG).

Méthode: Au sein d'une cohorte monocentrique de 409 patients avec ACG, nous avons identifié 104 patients présentant une manifestation ophtalmologique au diagnostic. Ils ont été comparés à 104 patients témoins, appareillés selon l'âge et le sexe, sans atteinte ophtalmologique issus de cette même cohorte.

Résultats: Comparés aux témoins, les patients présentant une atteinte ophtalmologique initiale présentaient moins de fièvre $(p=0.0006)$, moins de pseudopolyarthrite rhizomélique $(p=0.02)$ et un syndrome inflammatoire biologique moindre $(\mathrm{p}=0.004)$. Un flou visuel (chez 60\% des patients), une amaurose fugace (chez 18\%), une diplopie (chez 13\%) et une cécité (chez 9\%) étaient les 4 symptômes décrits au diagnostic. Une neuropathie optique ischémique antérieure (NOIA) a été retrouvée chez $47(45 \%)$ des patients, suivi par l'occlusion de l'artère centrale de la rétine (OACR) pour 15 d'entre eux (15\%). Le délais d'introduction de la corticothérapie ne différait pas dans les 2 groupes $(\mathrm{p}=0.06)$. Parmi les 60 patients avec NOIA et/ou OACR $39(65 \%)$ ont gardé une cécité définitive ou un dommage visuel majeur en dépit du recours aux boli de corticoïdes pour $45(75 \%)$ d'entre eux. 4\% des patients avec atteinte ophtalmologique initiale ont présenté un nouvel événement ischémique (NOIA).

Conclusion: Une atteinte ophtalmologique a été retrouvée chez $1 / 4$ de nos patients avec ACG. La NOIA est toujours associée au pronostic visuel le plus péjoratif, et l'utilisation de boli de corticoïdes ne réduit pas le risque de cécité définitive dans notre cohorte.

MOTS CLES : Artérite à cellules géantes ; manifestations ophtalmologiques, cécité, glucocorticoïdes, boli de méthylprednisolone.

TITRE DE LA THESE EN ANGLAIS : Characteristics and outcomes of patients with ophthalmologic involvement in giant-cell arteritis: a case-control study.

RESUME DE LA THESE EN ANGLAIS :

Purpose: To describe the characteristics and outcome of patients with giant-cell arteritis (GCA)related ophthalmologic involvement at diagnosis.

Methods: In a retrospective single-center cohort of 409 consecutive patients with GCA, we retrieved 104 patients with visual symptoms at GCA diagnosis and we compared them to 104 age- and sexmatched controls without ophthalmologic involvement. Each visual symptom was associated to an ophthalmologic diagnosis that was centrally re-assessed by an ophthalmologist.

Results: Compared to controls, patients with visual symptoms showed less fever $(p=0.0006)$, less polymyalgia rheumatica $(p=0.02)$ and lower acute phase reactants $(p=0.004)$. Blurred vision (in $60 \%$ of patients), amaurosis fugax (in 18\%), diplopia (in 13\%) and permanent visual loss (in 9\%) were the four visual symptoms described by patients before GCA diagnosis. Anterior ischemic optic neuropathy (AION) was found in $47(45 \%)$ patients, followed by central retinal artery occlusion (CRAO) in $15(15 \%)$. Two patients had both involvements. The delay of glucocorticoids initiation was not different between patients with and without visual symptoms $(p=0.06)$. Among the 60 patients with initial AION and/or CRAO, 39 (65\%) kept definite blindness or important visual damage, although $45(75 \%)$ had received intravenous (IV) pulses of methylprednisolone. A new ischemic event (AION in all cases) occurred in $4 \%$ of patients with visual symptoms despite the initiation of treatment.

Conclusion: Ophthalmologic involvement was observed in one-quarter of our GCA patients. AION is still associated with the worst visual prognosis, and IV methylprednisolone pulses did not reduce the risk of blindness in our study.

KEY WORDS : giant-cell arteritis; ophthalmologic involvement; visual loss; glucocorticoids; methylprednisolone pulses. 